\title{
CS-18 - Tierras Altas Orientales, Jalapa, el problema de los asentamientos multiétnicos
}

\author{
Eastern Highlands, Jalapa, The problem of multiethnic settlements
}

\author{
Christopher S. Martínez \\ Departamento de Investigaciones de Sur Oriente, Centro Universitario de Sur-Oriente, \\ Universidad de San Carlos de Guatemala
}

*Autor al que se dirige correspondencia: proyecto_jalapa@hotmail.com

\section{Resumen}

L as Tierras Altas Orientales han sido poco estudiadas debido a la complejidad que presentan en cuanto a Llos distintos grupos étnicos que las habitaron, aunado a la destrucción de los sitios por el crecimiento de la frontera agrícola y pecuaria. Por lo tanto, se hizo necesario iniciar un proyecto de registro de sitios y patrones de asentamiento. Para ello se recurrió al trabajo de campo, transitando los cerros y montañas, así como las riveras de ríos, en busca de asentamientos prehispánicos que no hubiesen sido reportados o para determinar el daño que, por los años, han sufrido. Se hicieron levantamientos topográficos con brújula y sistemas deposisionamiento global (GPS); también se recolectaron materiales culturales para su posterior análisis en laboratorio. El proceso de gabinete fue fructifero ya que permitio determinar los materiales locales y foráneos, de igual manera, el registro de los sitios permitió realizar una tipología de asentamientos de acuerdo a las distintas temporalidades de los vestigios localizados, lo que nos permitió comprender la compleja interacción social que se desarrolló en ese territorio. La información recabada durante los años de investigación ha determinado que esta zona tuvo múltiples migraciones y cambios de poder, registrado en la evidencia material, llegando a un declive de población para el Postclásico.

Palabras claves: Xincas, pokom, poqomames, cambios culturales, cerámica

\section{Abstract}

$\mathrm{T}$ he Eastern Highlands have been less studied, due to the complexity of the different ethnic groups that inhabited in, this together with the destruction of the sites by the growth of the agricultural and cattle frontier, reason why became necessary Initiate a site registration project and settlement patterns. Field work was used to pursue the goal, covering the hills and mountains, as well as the riverbanks in search of pre-Hispanic settlements that had not been reported or to determine the damage they have suffered over time. Topographic surveys with compass and GPS, as well as collection of cultural materials, were made for later analysis in the laboratory. The cabinet process was a success because it allowed to determining the local and foreign materials; In the same way the registration of the sites allowed to realize a typology of settlements according to the different temporalities of the vestiges located, which allowed us to understand how complex was the social interaction in this territory. The information collected has determined that this area was a place of ethnic complexity, with multiple migrations and changes of power, registered in the material evidence, reaching a decline of population for the Postclassic.

Key words: Xincas, Pokom, Poqomames, cultural changes, pottery 